\title{
Pengembangan model pembelajaran berbasis visual dengan pendekatan komunikasi total membuat pola dasar busana wanita untuk tunarungu
}

\author{
Siti Asmunah \\ ${ }^{1}$ Program Studi Pendidikan Luar Biasa, Program Pascasarjana, Universitas Negeri Surabaya \\ * Corresponding Author. E-mail: as0mu0nah@gmail.com
}

\begin{abstract}
Abstrak: Penelitian ini dilatarbelakangi oleh kegiatan pembelajaran membuat pola dasar busana wanita di SLBB Dharmawanita Kab. Sidoarjo berlangsung tidak teratur. Untuk mengatasi masalah tersebut difokuskan pada masalah model pembelajaran tata busana membuat pola dasar busana wanita yang diberikan guru di sekolah. Sehingga perlu dikembangkan model pembelajaran berbasis visual dengan pendekatan komtal membuat pola dasar busana wanita, untuk guru dalam memberikan pembelajaran materi membuat pola dasar busana wanita pada siswa kelas X. Penelitian ini bertujuan untuk mendeskripsikan tahapan, hasil produk dan kelayakan model pembelajaran berbasis visual dengan pendekatan komtal pada pokok bahasan membuat pola dasar busana wanita pasa anak tunarungu. Penelitian ini menggunakan pendekatan kuantitatif dan kualitatif dengan jenis penelitian research and development $(R \& D)$ dengan mengadaptasi model pengembangan Thiagarajan atau dikenal dengan Four D yang terdiri atas empat tahapan yaitu (1) define, (2) design, (3) develop, dan (4) disseminate. Bentuk pengadaptasian model ini dengan hanya melakukan 3 tahapan saja, yaitu (1) define, (2) design, dan (3) develop. Pada tahap define dilakukan 5 langkah pokok yaitu : (a) analisis awal akhir, (b) analisis anak, (c) analisis tugas, (d) analisis konsep, dan (e) spesifikasi tujuan program. Pada tahap design dilakukan 3 langkah pokok, (a) pemilihan media, (b) pemilihan format, dan (c) perancangan awal. Sedangkan pada tahap develop, dilakukan validasi ahli dari segi pembelajaran dan materi. Hasil penelitian ini berupa panduan mengenai tahap pelaksanaan model pembelajaran berbasis visual membuat pola dasar busana wanita dengan pendekatan komtal yang dituangkan melalui sintaks-sintaks. Kelayakan panduan mengenai tahap pelaksanaan model pembelajaran tersebut menurut ahli pembelajaran tunarungu, memperoleh nilai 3 artinya program ini berada pada kategori baik dari segi pembelajaran dan layak digunakan dan menurut ahli materi tata busana, memperoleh nilai 3,75 artinya program ini berada pada kategori baik dari segi materi dan layak digunakan.Uji terbatas menunjukkan (1) kemampuan guru mengelola pembelajaran pada pertemuan pertama telah menemui kesesuaian dengan kategori baik dengan prosentase keterlaksanaan 97,8\%. Pertemuan kedua dengan kategori baik dengan prosentase keterlaksanaan 99\%, dan pertemuan ketiga juga mencapai kategori baik dengan prosesntase keterlaksanaan 99\%. (2) Unjuk kerja siswa selama pembelajaran, inisial Su mencapai prosentase 100\%; inisial Fi mencapai prosentase 100\%; inisial Ya mencapai prosentase 99,33; inisial Al mencapai prosentase 98,67\%; inisial Na mencapai prosentase 98\%; dan inisial Dy mencapai prosentase 99\%. Disimpulkan bahwa model pembelajaran berbasis visual dengan pendekatan komtal secara konsep maupun secara empirik layak dan efektif.
\end{abstract}

Kata Kunci: Model Pembelajaran Berbasis Visual, Pendekatan Komunikasi Total, Pola Dasar Busana Wanita

\section{Development of visual based learning model with total communication approach to make female women's basic patterns for shooting}

\begin{abstract}
The background of this research was the activity that ran irregularly in SLB-B Dharmawanita Sidoarjo to make the basic pattern of women's clothing. The focus of the problem was the fashion learning model given by teacher in school to make the basic pattern of women's clothing. Thus, it is necessary to develop a visualbased learning model with total communication approach to make the basic pattern of women's clothing, for teachers, in providing learning material to make the basic pattern of women's clothing in students of tenth class. This study was aimed to describe the stages, product results, and feasibility of visual-based learning model with total communication approach on the subject to make the basic pattern of women's clothing for the hearing impairment child. This research used quantitative and qualitative approach using research and development ( $\mathrm{R} \&$ D) adapting Thiagarajan development model known as Four D consisting of four stages: (1) define, (2) design, (3) develop, and (4) disseminate. The 3 stages were conducted, namely (1) define, (2) design, and (3) develop. In the define phase were five main steps, as follows (a) preliminary analysis, (b) child analysis, (c) task analysis, (d) concept analysis, and (e) program objectives specification. In the design stage were 3 (three) basic steps taken, (a) media selection, (b) format selection, and (c) preliminary design. In the stage of develop was validation of experts in forms of learning and material. The result of this research was guidance on the stage of implementation of visual-based learning model to make the basic pattern of women's clothing using total
\end{abstract}


communication approach in the form of syntax. The feasibility of the guidance on the implementation stage for learning model according to expert got 3 meaning that the program was categorized as good in terms of learning and appropriate to use and according to the material expert of the dress code was 3.75 meaning that the program was categorized as good in terms of material and feasible to use. The limited test shows (1) the ability of the teacher to manage the learning process at the first meeting was suitable and categorized as good, in which the percentage of implementation was $97.8 \%$. The second meeting was categorized as good with the percentage of $99 \%$ in implementation. The third meeting was categorized as good with the $99 \%$ implementation procession. (2) in the students' performance while learning, The initial Su was 100\%; The initial Fi was 100\% percent; The initial Ya was 99.33; The initial Al was 98.67\%; The initial Na was 98\%; And The initial Dy was 99\%. It was concluded that visual-based learning model using total communication approach and was empirically feasible and effective.

Keywords: Visual Based Learning Model, Total Communication Approach, Basic Pattern of Women's Clothing

\section{PENDAHULUAN}

Ketidakmampuan anak tunarungu untuk mendengar bunyi mengakibatkan hambatan dalam memperoleh informasi melalui pendengaran. Akibat kurang berfungsinya pendengaran, siswa tunarungu mengalihkan pengamatannya kepada mata, maka siswa tunarungu disebut sebagai "Insan Pemata" (Ruyati, 2013:4) "One study demonstrates that hearing children and deaf children employ very different learning, deaf children primarily rely on visual chues." Artinya sebuah penelitian meninjukkan bahwa anak yang mendengar dan anak tunarungu menggunakan strategi pembelajaran yang sangat berbeda dan belajar bahasa Inggris dengan cara yang tidak sama. Anak tunarngu terutama mengandalkan pada petunjuk visual (de Vicenties, 2011:6).

Berdasarkan hasil pengamatan (11 Januari2016) dan wawancara (2 Juni 2016) di SLB-B Dharma Wanita Kab. Sidoarjo mengenai kegiatan pembelajaran membuat pola dasar busana wanita, dimana kegiatan pembelajaran bagi siswa tunarungu SMALB berlangsung tidak teratur sehingga siswa lupa pada pelajaran yang sudah diberikan. Sekalipun telah menggunakan media dalam pembelajaran, namun kurang dapat dimaksimalkan penggunaanya oleh guru, yaitu hanya menggunakan buku pola dasar. Siswa mempergunakan media ini sendiri dan tidak dibimbing oleh guru secara maksimal. Guru merasa kesulitan mengajarkan membuat pola dasar busana dengan siswa lebih dari satu.

Hal tersebut dilakukan karena keterbatasan pengetahuan yang dimiliki oleh guru dalam membuat pola dasar busana wanita, sehingga mengakibatkan pembelajaran membuat pola dasar busana wanita tidak optimal. Hal ini memerlukan perhatian lebih, saat dalam kurikulum menjadi kompetensi yang harus dimiliki anak.

Sehingga diperlukan adanya inovasi dalam pembelajaran membuat pola dasar busana wanita. Inovasi yang dilakukan harus memperhatikan karakteristik siswa tunarungu itu sendiri. Hal yang dapat dilakukan dengan membangun kegiatan pembelajaran berbasis visual dengan siswa menggunakan indera penglihatan, praktik dan melibatkan fisik (DePorter, 2002).

Visualisasi merupakan salah satu karakteristik materi pembelajaran bagi siswa tunarungu (Wardani, dkk, 2002:5, 29). Pendengaran siswa tunarungu kurang berfungsi, maka melalui indera penglihatan siswa tunarungu berusaha memperoleh informasi, untuk itu semua pembelajaran yang diberikan oleh guru hendaknya dapat disampaikan dengan media.

Dalam pembelajaran membuat pola dasar busana wanita media yang digunakan gabungan dari media berbasis visual (gambar teknik strip story), media berbasis manusia (instruktur atau guru), media berbasis cetak (buku penuntun) dan/atau media Microsoft powerpoint (gambar teknik strip story digabung dengan teks). Semua media tersebut pada dasarnya berbasis visual.

Berdasarkan pemaparan di atas, diperlukan adanya pengembangan model pembelajaran berbasis visual dengan pendekatan komtal membuat pola dasar busana wanita di sekolah luar biasa tunarungu. Model pembelajaran berbasis visual ini dikembangkan sesuai dengan sintaks-sintaks atau tahapan pembelajaran yang sesuai. Pembelajaran visual dalam membuat pola busana wanita merupakan gambar pola busana yang disajikan dengan bertahap dan merupakan proses pembuatan pola. Pembelajaran visual dalam mengukur tubuh pelangan dengan menggunakan model dari guru/siswa. Begitu juga pembelajaran visual pada pengolahan hasil pengukuran tubuh pelanggan disajikan dengan 


\title{
JPK (J urnal Pendidikan Khusus), 14 (1), 2018- 11
}

\author{
Siti Asmunah
}

menggunakan microsoft powerpoint. Komunikasi yang digunakan dalam pembelajaran membuat pola dasar busana wanita, menggunakan komunikasi total.

\section{METODE}

Penelitian ini merupakan penelitian pengembangan. Pengembangan model pembelajaran berbasis visual dengan pendekatan komtal dalam penelitian ini menggunakan model Thiagarajan dan Sammel yang dikenal dengan 4-D yaitu pendefinisian (define), perancangan (design), pengembangan (develop), dan penyebaran (disseminate). Namun dalam penelitian ini hanya akan dikembangkan hingga tahap pengembangan saja (develop), tahap penyebaran (disseminate) tidak dilakukan secara luas karena keterbatasan waktu dan dana.

Pengumpulan data dilakukan dengan dua instrumen yakni: (1) Lembar Validasi untuk keperluan validasi ahli (2) Lembar observasi pengimplementasian untuk keperluan mengetahui tingkat keberhasilan siswa dalam melaksanakan pembelajaran berbasis visual dengan pendekatan komtal membuat pola dasar busana wanita pada kelompok kecil yang terdiri dari enam siswa kelas $\mathrm{X}$ SLB-B Dharmawanita Sidoarjo dan untuk keperluan memperoleh informasi berupa saran dan masukan dari guru mengenai model pembelajaran berbasis visual dengan pendekatan komtal membuat pola dasar busana wanita untuk siswa tunarungu.

Subjek uji dalam penelitian pengembangan ini adalah:

1. Ahli Pembelajaran Tunarungu yaitu Dra. Hj.Endang Purbaningrum, M.Kes. Dosen sekaligus Kepala Jurusan Pendidikan Luar Biasa, Fakultas Ilmu Pendidikan, Unesa

2. Ahli Materi Tata Busana wanita yaitu Dr. Marniati, M.Pd. Dosen sekaligus Kepala Jurusan Pendidikan Kesejahteraan dan Kekeluargaan, Fakultas Teknik, Unesa

3. Pengguna Produk yaitu guru kelas X SLB-B Dharma Wanita Sidoarjo, Ibu Nurul Hidayah, S.Pd., Ibu Soebidah, S.Pd., dan Bapak Bambang Sulistiono, S.Pd.

Data yang terkumpul dalam penelitian ini dianalisis menggunakan pendekatan kuantitatif dan kualitatif. Teknik analisis data Pada penelitian ini menggunakan dua tehnik, yaitu:

\section{Analisis Hasil Validasi Ahli}

Hasil validasi Ahli pembelajaran tunarungu dan ahli materi tata busana wanita terhadap buku panduan kegiatan pembelajaran berbasis visual dengan pendekatan komtal membuat pola dasar busana wanita dianalisis dengan menggunakan rumus menurut Djatun (1999) berikut ini:

$\mathrm{M}_{\mathrm{x}}=\frac{\sum x}{N}$

Keterangan:

$\mathrm{M}_{\mathrm{x}}=$ Rata-rata kelompok $\mathrm{x}$

$\sum \mathrm{x}=$ Skor

$\mathrm{N}=$ Jumlah item

Setelah diketahui hasil kelayakan melalui analisis data kemudian dilakukan interpretasi hasil melalui daftar kriteria kelayakan yang dapat dilihat pada tabel sebagai berikut.

Tabel 1. Kriteria penilaian Validator terhadap Model Pembelajaran

\begin{tabular}{ccc}
\hline No & Rata-rata Nilai dari Validator & Keterangan \\
\hline 1 & $0,0 \leq \mathrm{Va}<0,99$ & Tidak Baik \\
\hline 2 & $1,0=\mathrm{Va}<1,99$ & Kurang Baik \\
\hline 3 & $2,0=\mathrm{Va}<2,99$ & Cukup Baik \\
\hline 4 & $3,0=\mathrm{Va}<3,99$ & Baik \\
\hline 5 & $4,0=\mathrm{Va}<4,99$ & Sangat Baik \\
\hline
\end{tabular}

\section{Analisis Hasil Uji Coba Lapangan}

Hasil uji coba lapangan terdiri dari a) hasil penilaian kemampuan guru mengola pembelajaran dan b) hasil penilaian unjuk kerja siswa. Skala yang digunakan dalam menentukan hasil kemampuan guru mengelola pembelajaran ini adalah skala Likert, kategorinya sebagai berikut: 


$$
\begin{array}{ll}
76 \%-100 \% & =\text { Sangat baik } \\
51 \%-75 \% & =\text { Baik } \\
26 \%-50 \% & =\text { Cukup } \\
0 \%-25 \% & =\text { Kurang }
\end{array}
$$

Skala yang digunakan dalam menentukan hasil unjuk kerja siswa dalam kegiatan pembelajaran adalah dengan skala penilaian sebagai berikut:

$\begin{array}{ll}0 \% & \text { : Tidak melakukan sama sekali } \\ 1 \%-25 \% & \text { : Tidak mampu } \\ 26 \%-50 \% & \text { : Mampu dengan banyak bantuan } \\ 51 \%-75 \% & \text { : Mampu dengan sedikit bantuan } \\ 76 \%-100 \% & \text { : Mampu }\end{array}$

\section{HASIL DAN PEMBAHASAN}

Hasil

\section{A. Deskripsi Hasil Model Pembelajaran Berbasis Visual dengan Pendekatan Komtal Membuat} Pola Dasar Busana Wanita

Berdasarkan hasil pengembangan model pembelajaran menggunakan model 4-D Thiagarajan, dkk, maka dihasilkan buku panduan model pembelajaran bagi guru SLB-B dalam mengajar tata busana materi membuat pola dasar busana wanita dengan menggunakan model pembelajaran berbasis visual dengan pendekatan komtal untuk siswa tunarungu. Program ini dikemas dalam bentuk buku dengan ukuran kertas A4, ketebalan \pm 89 lembar dan dijilid soft cover. Deskripsi bagian-bagian model pembelajaran berbasis visual dengan pendekatan komtal membuat pola dasar busana wanita adalah sebagai berikut.

1. Cover

Sampul/cover program ini dengan gambar pola dasar dan meteran sebagai begroundnya disertai dengan gambar langkah-langkah membuat pola dasar busana wanita yang ditampilkan dengan power point.

2. Kata Pengantar

Kata pengantar berisikan ucapan syukur peneliti karena telah mampu menyelesaikan buku panduan untuk guru dalam memberikan model pembelajaran berbasis visual dengan pendekatan komtal membuat pola dasar busana wanita kepada siswa tunarungu.

3. Daftar Isi

Daftar isi menjelaskan tentang halaman dari masing-masing sub bagian. Daftar isi ini bertujuan untuk memudahkan guru/pembaca dalam membaca buku panduan model pembelajaran berbasis visual ini.

4. Model pembelajaran berbasis visual dengan pendekatan komtal membuat pola dasar busana wanita

a. Bagian I

Bagian I terdiri dari 1 halaman. Pada bagian ini berisi tentang latar belakang dari model pembelajaran yang dikembangkan.

b. Bagian II

Bagian II terdiri dari 15 halaman. Pada bagian II ini berisikan tentang media apa saja yang digunakan serta tahapan-tahapan dalam melaksana-kan model pembelajaran berbasis visual dengan pendekatan komtal membuat pola dasar busana wanita di kelas. Tahap pelaksanaan model pembelajaran berbasis visual dengan pendekatan komtal membuat pola dasar busana wanita ini terdiri dari lima tahap. Tahap I merupakan tahap persiapan, tahap II adalah penyampaian, dan tahap III merupakan tahap pembimbingan, tahap IV adalah pelatian, dan tahap V merupakan tahap penampilan hasil. Dalam pembuatan pola dasar busana wanita, terdiri atas tiga kompetensi dasar yaitu mengukur tubuh pelanggan, mengolah hasil pengukuran, dan membuat pola dasar busana wanita. Setiap kompetensi dasar terdiri atas lima tahapan.

c. Bagian III

Pada bagian III terdiri dari materi pengukuran tubuh pelanggan dan langkah-langkah membuat pola dasar busana wanita.

1) Mengukur tubuh pelanggan

2) Mengola hasil pengukuran 


\section{J PK (J urnal Pendidikan Khusus), 14 (1), 2018- 13}

Siti Asmunah

3) Membuat pola dasar busana wanita

\section{B. Deskripsi Kelayakan Model Pembelajaran Berbasis Visual dengan Pendekatan Komtal Membuat Pola Dasar Wanita.}

Kelayakan model pembelajaran berbasis visual dengan pendekatan komtal membuat pola dasar busana wanita ditentukan dari hasil validasi secara konsep dan secara empirik.

Adapun deskripsi hasil kelayakan yang dimaksudkan didapat dari hasil validasi ahli (pembelajaran dan materi), pengamatan kemampuan guru mengelola pembelajaran, serta pengamatan unjuk kerja siswa selama kegiatan pembelajaran.

1. Validasi Konsep

a. Validasi ahli pembelajaran

Berdasarkan analisis data dan daftar kriteria kelayakan dapat disimpulkan bahwa hasil validasi pembelajaran model pembelajaran berbasis visual dengan pendekatan komtal membuat pola dasar busana wanita memperoleh nilai 3 artinya program ini berada pada kategori baik dari segi pembelajaran dan layak digunakan.

b. Validasi ahli materi

Berdasarkan analisis data dan daftar kriteria kelayakan dapat disimpulkan bahwa hasil validasi materi model pembelajaran berbasis visual dengan pendekatan komtal membuat pola dasar busana wanita memperoleh nilai 3,75 artinya program ini berada pada kategori baik dari segi materi dan layak digunakan.

2. Validasi Empirik

a. Uji coba lapangan

1) Kemampuan guru mengola pembelajaran.

Berdasarkan data yang diperoleh bahwa kemampuan guru mengelola pembelajaran dengan menggunakan model pembelajaran berbasis visual dengan pendekatan komtal membuat pola dasar busana wanita di SLB-B Dharma Wanita Kab. Sidoarjo pada pertemuan pertama telah menemui kesesuaian dengan kategori baik dengan prosentase keterlaksanaan 97,8\%. Pertemuan kedua dengan kategori sangat baik dengan prosentase keterlaksanaan 99\%, dan pertemuan ketiga juga mencapai kategori baik dengan prosesntase keterlaksanaan 99\%.

2) Unjuk kerja siswa selama pembelajaran

Berdasarkan deskripsi unjuk kerja siswa, bahwa kemampuan siswa dalam melaksanakan instruksi yang diberikan guru dengan menggunakan model pembelajaran berbasis visual dengan pendekatan komtal membuat pola dasar busana wanita di SLB-B Dharma Wanita Kab. Sidoarjo, dari pertemuan pertama sampai dengan pertemuan ketiga telah menemui kesesuaian dengan kategori baik.

C. Keefektifan Model Pembelajaran Berbasis Visual dengan Pendekatan Komunikasi Total Membuat Pola Dasar Busana Wanita untuk Tunarungu

Model pembelajaran berbasis visual dengan pendekatan komtal yang telah dikembangkan dan telah divalidasi oleh para ahli dan dinyatakan layak digunakan sebagai model pembelajaran dalam kegiatan belajar mengajar, selanjutnya model pembelajaran berbasis visual dengan pendekatan komtal membuat pola dasar busana wanita diujicobakan dengan ujicoba terbatas di SLB-B Dharma Wanita Kab. Sidoarjo, dengan subyek ujicoba ada 6 siswa dan yang bertindak sebagai pengamat selama kegiatan pembelajaran berlangsung adalah Ibu Nurul Hidayah, Bapak Bambang Sulistiono, dan Ibu Soebidah, dari pertemuan pertama sampai dengan pertemuan ketiga telah menemui kesesuaian dengan kategori baik. itu artinya bahwa model pembelajaran berbasis visual dengan pendekatan komtal membuat pola dasar busana wanita untuk tunarungu efektif digunakan.

Berdasarkan penilaian unjuk kerja siswa dan deskripsi unjuk kerja siswa, diperoleh skor bahwa kemampuan siswa dalam melaksanakan instruksi yang diberikan guru dengan menggunakan model pembelajaran berbasis visual dengan pendekatan komtal membuat pola dasar busana wanita di SLB-B Dharma Wanita Kab. Sidoarjo, dari pertemuan pertama sampai dengan pertemuan ketiga telah menemui kesesuaian dengan kategori baik. itu artinya bahwa model pembelajaran berbasis visual dengan pendekatan komtal membuat pola dasar busana wanita untuk tunarungu efektif digunakan 
Siti Asmunah

\section{Pembahasan}

Berdasarkan hasil analisis data dari pengembangan model pembelajaran berbasis visual dengan pendekatan komtal membuat pola dasar busana wanita dapat dilihat bahwa model pembelajaran berbasis visual dengan pendekatan komtal membuat pola dasar busana wanita yang dikembangkan ini telah divalidasi oleh para ahli dan telah dinyatakan kelayakannya oleh para ahli serta telah dilakukan uji coba skala kecil.

\section{A. Hasil Produk Model Pembelajaran Berbasis Visual dengan Pendekatan Komunikasi Total Membuat Pola Dasar Busana Wanita untuk Tunarungu \\ 1. Diskusi Hasil Validasi Ahli}

a. Validasi Ahli Pembelajaran

Dari segi pembelajaran, model pembelajaran berbasis visual dengan pendekatan komtal membuat pola dasar busana wanita ini memperoleh skor kelayakan 3 yang artinya layak digunakan karena telah sesuai dengan tahap-tahap pembelajaran berbasis visual dengan pendekatan komtal. Sehingga dapat disimpulkan bahwa draft instrument model pembelajaran berbasis visual dengan pendekatan komtal membuat pola dasar busana wanita dari segi pembelajaran layak dan dapat digunakan guru dalam upaya memberikan dalam pembelajaran yang inovatif, mudah, dan menyenangkan bagi anak tunarungu.

b. Validasi Ahli Materi

Dari segi materi, model pembelajaran berbasis visual dengan pendekatan komtal membuat pola dasar busana wanita ini memperoleh skor 3,75 yang artinya layak untuk digunakan dalam pembelajaran keterampilan tata busana membuat pola dasar busana wanita bagi guru SLB-B karena telah sesuai dengan karakteristik visual siswa tunarungu. Sehingga dapat disimpulkan bahwa, draft instrument model pembelajaran berbasis visual dengan pendekatan komtal membuat pola dasar busana wanita dari aspek materi layak dan dapat digunakan sebagai model pembelajaran di kelas bagi guru dalam memberikan pembelajaran keterampilan tata busana pada pokok bahasan membuat pola dasar busana wanita dengan cara yang inovatif, menyenangkan, dan mudah dipahami bagi anak tunarungu.

B. Uji Coba Lapangan

1. Kemampuan Guru mengelola Pembelajaran

Kemampuan guru mengelola pembelajaran merupakan faktor utama yang menentukan keberhasilan kegiatan pembelajaran. Hasil pengamatan kemampuan guru dalam mengelola pembelajaran telah dianalisis menggunakan statistik deskriftif dengan prosentase yang menunjukkan bahwa skor ratarata yang diperoleh guru berada dalam kriteria sangat baik untuk pertemuan pertama sampai dengan pertemuan ketiga.

2. Unjuk Kerja Siswa

Hasil pengamatan terhadap unjuk kerja siswa selama berlangsungnya pembelajaran dengan materi pengukuran tubuh pelanggan dan membuat pola dasar busana wanita, menunjukkan bahwa pertemuan 1, 2, dan 3, prosentase unjuk kerja siswa pada tiap aspek maupun secara keseluruhan adalah baik. Berdasarkan hal tersebut dapat disimpulkan bahwa unjuk kerja siswa dalam pembelajaran ini tercapai, yang berarti pembelajaran yang dilakukan dengan berorientasi model pembelajaran berbasis visual dengan pendekatan komtal membuat pola dasar busana wanita dapat mengaktifkan siswa.

\section{Perbandingan dengan Hasil Penelitian Sejenis Terdahulu}

Berdasarkan hasil penelitian yang dilkukan oleh Achidatun \& Nur (2014) dalam penelitian mengemukakan bahwa penerapan media visual berupa gambar, poster, contoh karya, grafik, dan memberikan contoh secara langsung dapat meningkatkan prestasi bekajar.

Hasil penelitian Achidatun \& Nur mempunyai persamaan dengan hasil penelitian pengembangan model pembelajaran berbasis visual dengan pendekatan komtal membuat pola dasar busana wanita untuk tunarungu. Letak persamaan hasilnya adalah bahwa pembelajaran visual untuk siswa tunarungu dapat meningkatkan keterampilan siswa. 


\section{SIMPULAN}

Berdasarkan hasil pengembangan dan tes pengembangan yang dilakukan diperoleh simpulan sebagai berikut.

1. Spesifikasi produk yang dihasilkan dalam penelitian ini berupa panduan mengenai tahap pelaksanaan model pembelajaran berbasis visual membuat pola dasar busana wanita dengan pendekatan komtal yang dituangkan melalui sintaks-sintaks.

2. Secara konsep, model pembelajaran berbasis visual dengan pendekatan komtal membuat pola dasar busana wanita yang dikembangkan layak menurut validator.

3. Setelah dilakukan uji coba kelompok kecil, model pembelajaran berbasis visual dengan pendekatan komtal membuat pola dasar busana wanita yang dihasilkan layak dan dapat digunakan dalam proses pembelajaran.

Berdasarkan simpulan-simpulan tersebut di atas, secara umum dapat disimpulkan bahwa model pembelajaran berbasis visual dengan pendekatan komtal secara konsep maupun secara empirik layak dan efektif.

\section{SARAN}

Saran yang diberikan dalam pengembangan prototype, model pembelajaran berbasis visual dengan pendekatan komtal membuat pola dasar busana wanita ini adalah sebagai berikut.

\section{Saran Pemanfaatan}

Pada pemanfaatan produk model pembelajaran berbasis visual dengan pendekatan komtal ini peneliti menyarankan:

a. Model pembelajaran berbasis visual dengan pendekatan komtal ini adalah suatu model pembelajaran yang dapat digunakan oleh guru sebagai petunjuk dalam melaksanakan pembelajaran. Dalam pelaksanaannya, diharapkan guru memahami terlebih dahulu langkahlangkah pembelajaran yang dimaksud sebelum mengaplikasikannya kepada siswa.

b. Dalam model pembelajaran berbasis visual dengan pendekatan komtal ini terdapat beberapa peralatan/media yang digunakan dalam melakukan pembelajaran yang harus disiapkan terlebih dahulu oleh guru sebelum proses pembelajaran dimulai.

\section{Saran diseminasi}

a. Dalam penelitian ini, hanya dilakukan uji coba dengan kelompok kecil. Oleh karena itu, penulis menyarankan kepada peneliti lain untuk melakukan uji coba dengan skala yang lebih besar agar menghasilkan produk yang maksimal.

b. Model pengembangan yang selanjutnya dapat dilakukan hingga pada tahap disseminate (penyebaran), proses penyebaran dapat dilakukan dengan mencetak buku model yang dikembangkan, publikasi, pelatihan.

\section{DAFTAR PUSTAKA}

Achidatun, U. N. (2014) Penerapan Media Visual untuk Meningkatkan Prestasi Belajar Siswa dalam Pembelajaran Kerajinan Batik di SMALB Tunarungu Bhakti Pertiwi Prambanan Daerah Istimewa Yogyakarta Diperoleh dari http://eprints.uny.ac.id/20615/1/Umi\%20Nur\%20Achidatun\%2009206241016.pdf

Afriani, R. M. (2013). Pelaksanaan Komunikasi Total dalam Pembelajaran Tematik pada Anak Tunarungu Kelas Persiapan SLB-B Cicendo Bandung Diperoleh dari http://repository.upi.edu/2718/1/S PLB 0900885 TITLE.pdf

Arifin, M. (2013). Bina Bicara Berbasis Komunikasi Total terhadap Kemampuan Bicara pada Anak $\begin{array}{llll}\text { Tunarungu } & \text { di } & \text { DMPLB. } & \text { Diperoleh }\end{array}$ http://jurnalmahasiswa.unesa.ac.id/article/5857/15/article.pdf.

Arsyad, A. (2005). Media Pembelajaran. Raja Grafindo Persada: Jakarta.

Artika, B. Y. (2010) Penggunaan Media Animasi Berbasis Pendekatan Komunikasi Total untuk Meningkatkan Kemampuan Membaca Pemahaman pada Anak Tunarungu Kelas Dasar V di SLB-B YRTRW Surakarta. Diperoleh dari https://digilib.uns.ac.id/dokumen/detail/12360 


\section{JPK (J urnal Pendidikan Khusus), 14 (1), 2018- 16}

Siti Asmunah

Aunurrahman. (2009). Belajar dan Pembelajaran. Bandung. Alfabeta.

Bintoro, T. 2015. Selayang Pandang Pendidikan bagi Anak Tunarungu di Indonesia. UNJ. Jurusan Pendidikan Luar Biasa Fakultas Ilmu Pendidikan.

DePorter, B.dkk. (1999). Quantum Learning. Bandung: Kaifa.

Dwijosumarto, A. (2006). Ortopedagogik Anak Tunarungu. Jakarta : Dirjen DIKTI.

Efendi, M., Triaswati, E., Hariyanto \& Pujiati. (2006). Penggunaan Media Ceritera Bergambar Berbasis Pendekatan Komunikasi Total untuk Meningkatkan Kemampuan Bahasa Anak Tunarungu Kelas Rendah di SLB Bagian B YPTB Malang. Diperoleh dari (http://www.ditnaga-dikti.org/ditnaga/files/sari_penelitian_ppkp-pips.pdf), diakses : 2 Juni 2016.

Efendi, M. (2006). Pengantar Psikopedagogik Anak Berkelainan. Jakarta: Bumi Aksara.

Handayasari, Y. (2014). Makalah Model Pembelajaran VAK. Diperoleh dari (blogspot.co.id/2014/12/model pembelajaran-vak-visualization.html.) Diakses : 4 Juni 2016.

Hasibuan \& Moedjiono. (2009). Proses Belajar Mengajar. Bandung. Remaja Rosdakarya.

Ibrahim, Sihkabuden, Suprijanta, \& Kustiawan. (2001). Media Pembelajaran : Bahan Sajian Program Pendidikan Akta Mengajar. Malang: FIP UM.

Ioana, Letitia Bucur. (2013). The Role Of Total Communication In Optimizing The Teaching-Learning Process For The Hearing Impaired Students. Diperoleh dari http://193.231.20.119/doctorat/teza/fisier/1161.

Jamila K. A Muhammad. (2008). Special Aducation for Special Children. Jakarta: Hikmah.

Joyce, Bruce. Marsha Weil dan Emily Calhoun. 2009. Models of Teaching. Pustaka Pelajar. Yogyakarta.

Khaer, Abu. (2008). Video Pembelajaran untuk Siswa Berkebutuhan Khusus Upaya Menemukan Suatu Model. Diperoleh dari (http://smkn2.dispendik.surabaya.go.id/download.php?id=35), diakses : 4 Juni 2016.

Lestari, A., Yarman, Syafriandi (2012). Penerapan Strategi Pembelajaran Matematika Berbasis Gaya Belajar Visual, Auditorial, Kinestetik. Diperoleh dari http://ejournal.unp.ac.id/students/index.php/pmat/article/viewFile/1135/827

Ludji, A., Geradus, U., \& Bire, J. (2014) Pengaruh Gaya Belajar Visual, Auditorial, dan Kinestetik terhadap Prestasi Belajar Siswa. Diperoleh dari http://journal.uny.ac.id/index.php/jk/article/download/5307/4603 diakses : 3 Mei 20017

Meier, Dave. (2002). The Accelerated Learning. Bandung Kaifa.

Nugroho, Tofiq. (2009). Metode Pembelajaran Metematika di sekolah Luar Biasa Tunarungu Melalui Komputer Untuk Peningkatan Hasil Belajar Siswa. Diperoleh dari (http://etd.eprints.ums.ac.id/3437/2/A410050094.pdf). diakses : 4 Juni 2016.

Power, Des dan Hyde, Merv (dalam Bintoro, Totok). Selayang Pandang Pendidikan bagi Anak Tunarungu di Indonesia. Jakarta: Jurusan Pendidikan Luar Biasa Fakultas Ilmu Pendidikan UNJ. 
Reed, C. M. (2009). ASL, Total Communication and Oralism: Identifying Shared Characteristics of School-Based Writing Intervention Programs for Deaf and Hard of Hearing Students, K-6 Diperoleh http://scholarship.shu.edu/cgi/viewcontent.cgi?article=1246\&context=dissertations

Riyanto,Y. (2010). Paradigma Baru Pembelajaran. Jakarta: Kencana.

Rose, C. \& Nicholl, M. (2002). Accelerated Learning. Bandung: Nuansa.

Ruyati, Y. (2013). Pembelajaran bagi Anak Tunarungu. Bandung. PPPPTK TK \& PLB.

Sari, H. N. M. (2013) Implementasi Metode VAK (Visual Auditori Kinestetik) guna Meningkatkan Motivasi Belajar Siswa Mata Pelajaran PKN Materi Penegakan HAM ( Kelas X Bina Prestasi 2 di MAN 2 Ponorogo Diperoleh dari http://eprints.umpo.ac.id/461/1/ARTIKEL\%20HEVI\%20N\%20MAYA\%20SARI\%2010311723 .pdf . diakses : 6 Mei 17.

Sediyono, E. \& Rahmarani R., Benazer. (2010). Model Pembelajaran Matematika untuk Siswa Kelas IV SDLB Penyandang Tunarungu dan Wicara dengan Metode Komtal Berbantuan Komputer. Diperoleh dari http://jutisi.maranatha.edu/index.php/jui/article/download/74/72 Diakses : 28 Juni 2016.

Situmorang, L. F. (2010). Pengaruh Pemberian Stimulasi Auditori-visual-taktil-kinestetik terhadap Perkembangan Perilaku Neonatus Prematur di Ruang Perinatologi RS Cipto Mangunkusumo Jakarta. Diperoleh dari http://www.lib.ui.ac.id/abstrakpdf?id=20282932\&lokasi=lokal diakses : 28 Juni 2016.

Soekarno. (2016). Buku Penuntun Membuat Pola Busana Tingkat Dasar. Jakarta. Gramedia Pustaka Utama.

Soekanto, S. (2009) Sosiologi Suatu Pengantar, Edisi Baru, Rajawali Pers Jakarta.

Somantri, S. (2012). Psikologi Anak Luar Biasa. Bandung. Refika Aditama.

Sudjana, N., dan Rivai, A. (2003). Teknologi Pengajaran. Bandung: Sinar Baru Algesindo.

Sumani, M. (2011). Belajar dan Pembelajaran. Bandung : PT. Remaja Rosdakarya.

Thiagarajan, Sivasailam, dkk. (1974). Instructional Development for Training Teachers of Eceptional Children. Minneapolis. Minnesota.

Trianto. (2007). Model-model Pembelajaran Inovatif Berorientasi Konstruktivistik. Jakarta. Prestasi Pustaka.

Trisnawati, D. A. O., Suarni, N. K., \& Marhaeni, A. A. I. N. (2013). Pengaruh Metode Pembelajaran Visual Word Wall dan Asesmen Projek terhadap Kemampuan Kosakata Bahasa Inggris Siswa $S D$ Kelas $V$ Kecamatan Gianyar Diperoleh dari http://pasca.undiksha.ac.id/ejournal/index.php/jurnal ep/article/view/691/476 diakses : 28 Juni 2016.

Wardani, Hernawati, Tati, \& Astati. (2002). Pengantar Pendidikan Luar Biasa. Jakarta: Pusat Penerbitan Universitas Terbuka. 